\title{
PUBLIC OPINION ANALYSIS ON STATE FOREST MANAGEMENT: STUDY AREA IN KAIŠIADORYS MUNICIPALITY
}

\author{
Marius KAVALIAUSKAS, Institute of Forest Management Planning and Wood science, Aleksandras Stulginskis University, Studentu \\ g. 13, LT-53362, Akademija, Kaunas raj., Lithuania, marius.kavaliauskas@ asu.lt (corresponding author) \\ Edgaras LINKEVIČIUS, Institute of Forest Management Planning and Wood science, Aleksandras Stulginskis University, Studentų g. \\ 13, LT-53362, Akademija, Kaunas raj., Lithuania, edgaras.linkevicius@asu.lt \\ Donatas JONIKAVIČIIUS, Institute of Forest Management Planning and Wood science, Aleksandras Stulginskis University, Studentų \\ g. 13, LT-53362, Akademija, Kaunas raj.. Lithuania, donatas.jonikavicius@asu.lt \\ Kornelija KOKANKAITE், Institute of Forest Management Planning and Wood science, Aleksandras Stulginskis University, Studentu \\ g. 13, LT-53362, Akademija, Kaunas raj., Lithuania, kornelija.kokankaite@ gmail.com
}

The relation between public and forest changes during the time. Public opinion and interests has considerable influence on decision making regarding forestry. Half of Lithuania's forests (circa 1.1 mill. ha) has state forest status and are managed by state forest enterprises (SFEs) under confidence rights. One of the most important strategic aims for SFEs is to meet public needs. Yet, public opinion and forestry facts mismatches. Therefore, this study aims to analyse prevailing opinion on forestry practices in state forests managed by Kaišiadorių SFE that are located in Kaišiadoriai municipality.

The sociological survey methodology was applied that was conducted involving respondents representing inhabitants over $18^{\text {th }}$ years old. Data was analysed by conducting frequency analysis. Results showed incorrect public opinion concerning with increase of forest coverage, sustainable cutting intensity and increasing environmental consideration. According to opinion of the respondents, the quality of the forests, afforestation and forest sanitary was well improved by Kaišiadorių SFE. It was determined the demand to develop more recreation infrastructure objects in Kaišiadorys municipality forests. The comparison between surveys conducted in 2007 and 2014 showed increasing amount of public that was quite well informed on forestry issues. Also, it determined changes in information sources concerning forestry. Results of the research stressed the necessity of the long-term strategy for the information dissemination.

Keywords: forestry, public opinion, survey, state forest, state forest enterprise

\section{INTRODUCTION}

Traditionally, the attitude of Lithuanian people to national forests is related with cultural spiritual and emotional aspects. Over last 100 years the ideologies, state institutions, state board, the structure of state forest administration were changing several times, therefore public interests in forests is complicated issue. Before World War II private forest ownership was developing, however, in 1940, all forest was expropriated due to occupation (Kairiūkštis, 2003). In soviet times, public attitude to state property (including forests that all of them had state status) was mocking, mostly because of the mismanagement (Directorate General..., 2009). The relation between state and public started radically changing after Lithuania regained independence in 1990. Planed system collapsed: process of restitution started, state forest enterprises (SFEs) became self-financing entities, working under market economy principles. Despite this, following social forestry problems became very actual: proportion between private and state forests, distribution of forests between state and private owners, profitableness of state and private forest sectors, which, social functions of SFEs and others. Some topics are still penetrating (e.g. amount of SFEs contribution to state budget).

According to Ministry of Environment (2014) over 25 years state forest area decreased twice (up to $1.1 \mathrm{mill}$. ha), while protected areas from quantitative and qualitative point of view drastically increased (especially in 1992). However, forest utilization has not changed (that means cutting intensity increased twice and it was $\sim 3$ mill. $\mathrm{m}^{3}$ in 2014). Brukas et al. (2011) characterized forestry branch in Lithuania, as heavily dominated by state organizations. State forests are managed by 42 SFEs, all of them are certified by FSC and forestry is based on sustainable forest management that meets global forest protection requirements. According Buchovska (2005) process of certification was the reason for the development of relations between SFE and public, while the driving force to develop participatory based processes in forest sector highly related with EU requirements and Lithuania's preparation process to join EU. As the priority for SFEs is economic efficiency, referring to Forest Act (2001), it satisfied public interests. Directorate General... (2011)

Copyright (C) 2015 The Authors. Published by Aleksandras Stulginskis University. This is an open-access article distributed under the terms of the Creative Commons Attribution License (CC-BY 4.0), which permits unrestricted use, distribution, and reproduction in any medium, provided the original author and source are credited. 
provided following social functions (social related activity giving no income) that are implemented by SFEs: (i) development of infrastructure for recreational, environment protection and scientific purposes; (ii) consultation of private forest owners; (iii) fire protection; (iv) road maintenance; (v) afforestation and etc.

Public attitude towards state forestry is important mostly due to the indirect impact on decision making processes (e.g. growing regulation on environment protection). Despite SFE's efforts in meeting public needs, a negative or controversial public opinion on forestry practices in Lithuania persists (Ministry of Environment, 2006). Sometimes forestry facts mismatches with public opinion, published by media (e.g. Vingrienė, 2013; Minkevičienè, 2015, Braziulis, 2015). Karazija (2011) provided the following common myths about forestry: (i) decreasing forest area; (ii) annual allowable cut is higher that annual increment; (iii) overestimated negative attitude towards clear cuts. It has to be stressed that "public opinion" in media is based on opinion of the experts, but not on the real surveys' results.. . Survey methodology investigating social forestry issues, is commonly in scientific research (Bliss and Martin, 1989). It was applied to analyse public opinion (Forestry Commission, 2011), interests of stakeholders', private forest owners, foresters and etc. (Lönnstedt, 1997; Hugosson and Ingermarson, 2004; Hokajärvi et al., 2009). Some countries for example UK, have adopted monitoring system that effectively evaluates public opinion on forestry issues and highlights public needs (Forestry Commission, 2011). Concerning to public opinion on the management in Lithuanian state forests only one survey initiated by Ministry of Environment (2006) is available. Regarding to experience of the authors, there are some surveys conducted by SFEs covering local issues, but they are not officially available.

Most of the scientific investigations (Mizaraitè, 2001; Pivoriūnas and Lazdinis, 2004; Mizaraite and Mizaras, 2005A; 2005B; Stanislovaitis et al., 2015) focused on private forest owners in Lithuania, so the analysis of public opinion on forestry in state forest issues is left aside. There is a lack of empirical data regarding to public attitude towards forestry as a whole, even though sustaining available references, prevailing opinion was incorrect to forestry practices and contrasted public with state forest managers. Therefore, this study aims to scrutinize public opinion and its forming causes on forestry practices in Kaišiadorys municipality's state forests.

\section{RESEARCH METHODS}

The study that was initiated by Kaišiadoriai SFE carried out in Kaišiadoriai municipality which is located in East-Central part of Lithuania (Figure 1) and covers 1087 $\mathrm{km}^{2}$. According to Lithuanian Department of the Statistics (2014) this municipality had $\sim 32$ thousand inhabitants. Circa 28 thousand of them were over 18 years old. $74 \%$ of population lived in the countryside. In 2014, forest coverage in Kaišiadoriai municipality was $31.6 \%$. Kaišiadoriai SFE managed $55.4 \%$ of these forests.

The primary questionnaire was developed according to methodological recommendations provided by Tidikis (2003), Rudzkienè (2005), Čekanavičius and Murauskas (2006) and Kardelis (2007). Further, the questionnaire was improved by involving experts from Kaišiadoriai SFE. In total, 23 closed-ended questions were formulated which addresses the following topics: (i) demographic

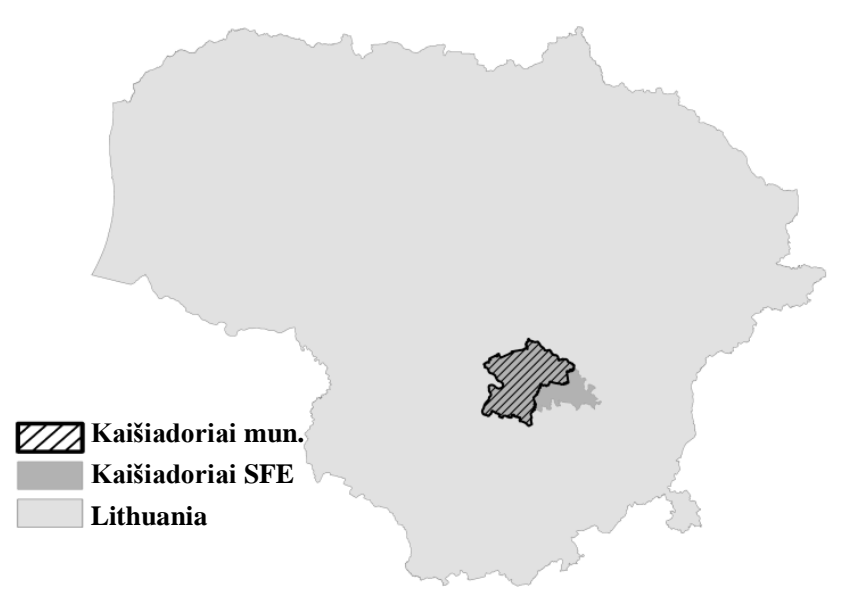

Figure 1. Study area description; (ii) environmental consideration; (iii) forest coverage; (iv) forest utilization; (v) forest reforestation, protection, improvement; (vi) social activity of Kaišiadoriai SFE.

The statistically based sample for Kaišiadoriai district municipality was determined according to Schwarze (1993) (Rudzkienè, 2005) approach. Professional interviewer was hired by Kaišiadoriai SFE to carry out the survey. The interviewer conducted standardized face-to-face interview, by interviewing respondents according to the prepared questionnaire. In this survey, rural and urban Kaišiadoriai municipality respondents over 18 years old were involved. Multi-stage random sampling approach was applied to reach the equal chance for inhabitants to be involved in the survey. Collected data was quantified and digitized in xlsx format for analysis. Data was processed by using MS Excel and STATISTICA applications. Frequency and cross tabulation analysis testing $X^{2}$ at significance level - 5\% were performed. Finally, survey results were compared with the survey results conducted in 2007 that was structured in a similar way but not based statistically.

\section{RESULTS}

According to statistically based sample requirements (Rudzkienè, 2005), 384 respondents needed to be surveyed to obtain a representative data. In total, 385 respondents were interviewed on $01^{\text {st }}-28^{\text {th }}$ July 2014 in Kaišiadoriai municipality. The main information that demographically describes respondents is provided in Figure 2.

According to the survey results, environmental protection (air cleaning, biodiversity, protection of species) was the most important (49\%) function of the state forest (Figure 3). Despite increasing environmental consideration during the last 15 years in Lithuania (e.g. established NATURA2000 territories, biodiversity, certification, protected nests of rare 
bird species and etc.), $33 \%$ of the respondents thought that it had to be further increased. Despite of the active observation of environmental consideration, respondents stated still existing demand of information dealing with protected areas in Kaišiadoriai municipality. Even more, $69 \%$ of respondents had no opinion or were not aware about forest certification processes (FSC) and its influence to Kaišiadoriai SFE performance (Figure 3). The concept of certification was not known because of the following assumptions: (i) certification principles, significance and its benefits to nature is rarely discussed in public media; (ii) exclusion of certified forests out of national system of protected territories; (iii) the conception of "certification" was melted between the conceptions of "conservation", "reserves" and "protected areas". Respondents, who thought that FSC influenced forestry practices, mostly were men (70 \%), with university education (23\%), living in countryside $(66 \%)$ and owning forest estate $(31 \%)$.

According to Ministry of Environment and State Forest Service (2009; 2014), from 2009 to 2014 forest area increased by 1.4 thousand ha in territory of Kaišiadoriai SFE. In the same manner, accumulated standing stock increased from $221 \mathrm{~m}^{3}$ to $251 \mathrm{~m}^{3}$. However, prevailing opinion was in contrast to statistical data. The majority of respondents $(72 \%)$ considered that forest coverage was decreasing or unchanging. Similarly $70 \%$ of them thought that fellings in state forests exceeded or was equal to annual growing increment. Thus, respondents were willing to reduce the intensity of cuttings (Figure 3). It shows that inappropriate sources of information on forestry may be the reason for incorrect opinion on forest coverage and cutting intensity. Respondents of age 40-49 (56\%) and over 60 years, with higher education and living in the countryside claimed that cutting intensity exceeded sustainable forestry principles. Yet, forest estate owners (33\%) and respondents over 40 years old, with higher education were convinced that forest coverage decreased or remained stable.

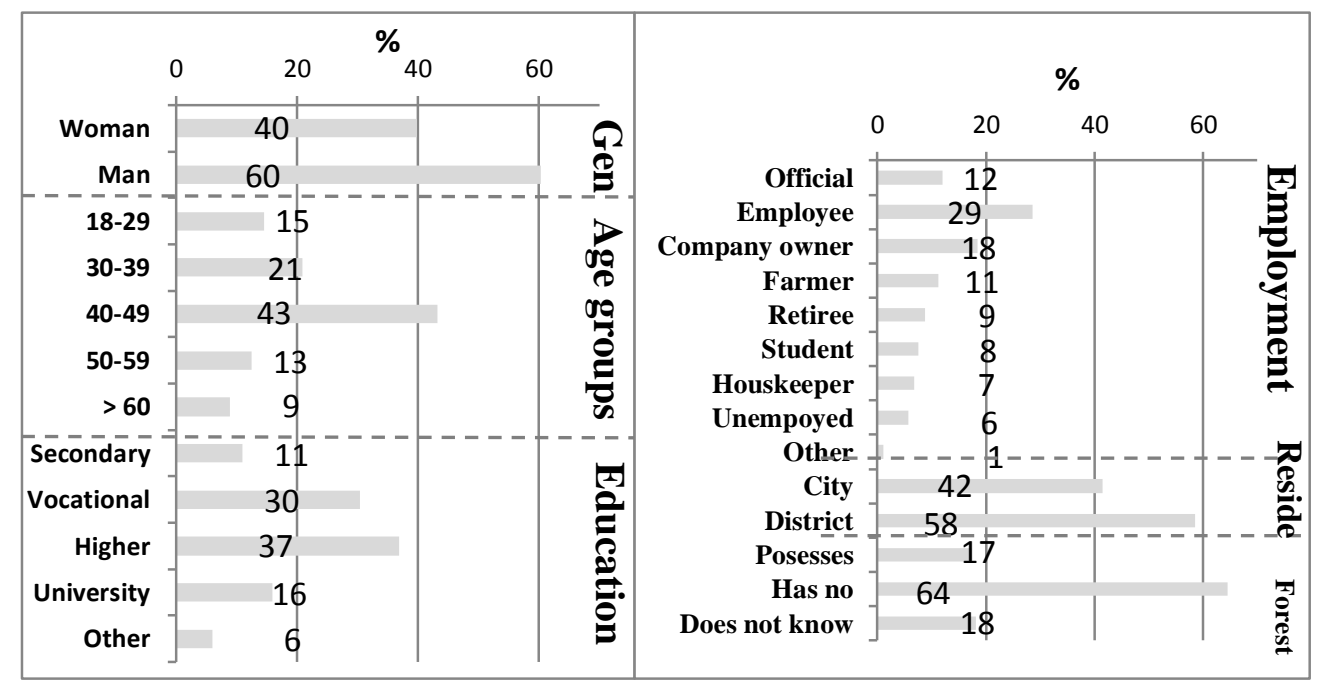

Figure 2. Demographic description of the respondents

Despite the contrary results obtained from the statistical data, respondents $(63 \%)$ had a positive attitude towards condition of state forests. For example, (men $65 \%$ ), respondents aging between 40-49 years(49\%), having university and higher education (60\%), owning companies (34\%) and forest estate owners (25\%) very positively ( $\geq 4$ marks out of 5) evaluated state forests' condition.

Respondents also highly rated afforestation (4 and 5 marks out of 5 were assign by $51 \%$ ) and forest protection (4 and 5 marks out of 5 assigned by $40 \%$ ). Forest afforestation was mentioned mostly by men (67\%), respondents aging 40-49 (49\%) and living in countryside (64\%). The highest rates (4 and 5 marks out of 5 were assign by $54 \%$ ) were given to the social activity (collaboration with children and locals, event on Christmas time called "Bearing Christmas home", events on artificial afforestation and placing nesting-box in spring time) in Kaišiadoriai SFE. Forest owners and respondents between 50-59 years old highly valued social activities. According to respondents the most interesting activities organized by SFE were listed as follows: maintenance (thinnings, fire protection and etc.) (20\%), final fellings $(20 \%)$, nature protection (20\%), recreation (23\%) and hunting (21\%) (Figure 3).

Results regarding dissemination of information showed that: more than $70 \%$ of respondents knew about state forest management activities in Kaišiadoriai municipality. Kaišiadoriai SFE was mostly well known by respondents aging between 30-59 years old (85\%), forest estate owners (47\%) and living in countryside (62 \%). However, half of the survey participators pointed out the need for more information about forest management in Kaišiadoriai SFE. The main respondents' information sources were relatives, friends, other familiar people (33\%) or personal visits to the forests (30 $\%)$. It was found, that only $20 \%$ of the respondents used media as the main information source.

Survey data showed frequent respondent's visits to Kaišiadoriai district municipality forests. Even more, $60 \%$ of the respondents visited forests not less than once per month. Actually, it was the reason for the positive attitude towards recreational infrastructure (billboards, quality of the wooden paths and etc.). Forest once per month was visited by respondents having higher education (43\%), working as employees (23\%) and company owners (30\%). Additionally, respondents were willing not only more outdoor furniture, arbours, fireplaces, paths and roads to be installed in forest but also with higher quality. Respondents over 50 years old, living in city highly valued quality of roads. Respondents also proposed to increase fines for the environmental offenders, to increase waste removing times from the forest and to faster 
processes of deadwood elimination in popular visiting places (Figure 3). Respondents with university education supported idea to increase fines for environmental offenders.

Survey results were compared with analogical survey results conducted by Kaišiadoriai SFE in 2007. The comparison showed that in second survey (2014) there were lower amount of the respondents who had a lack of information about forestry activities in state forests. It is important to stress that young generation (18-29 years old respondents) was less interested in forestry activities than in 2007. Generally, survey showed increased positive opinion on forest conditions and forestry. Environmental protection was the most important function for respondents' groups in both 2007 and 2014 surveys. Nevertheless, the popularity of economic function increased. The increased share of respondents who had no opinion on environment protection in forestry also shows low efficiency of information dissemination activities. Finally, second survey pointed out $50 \%$ decrease of respondents' willingness to raise the level of environmental protection in forestry.

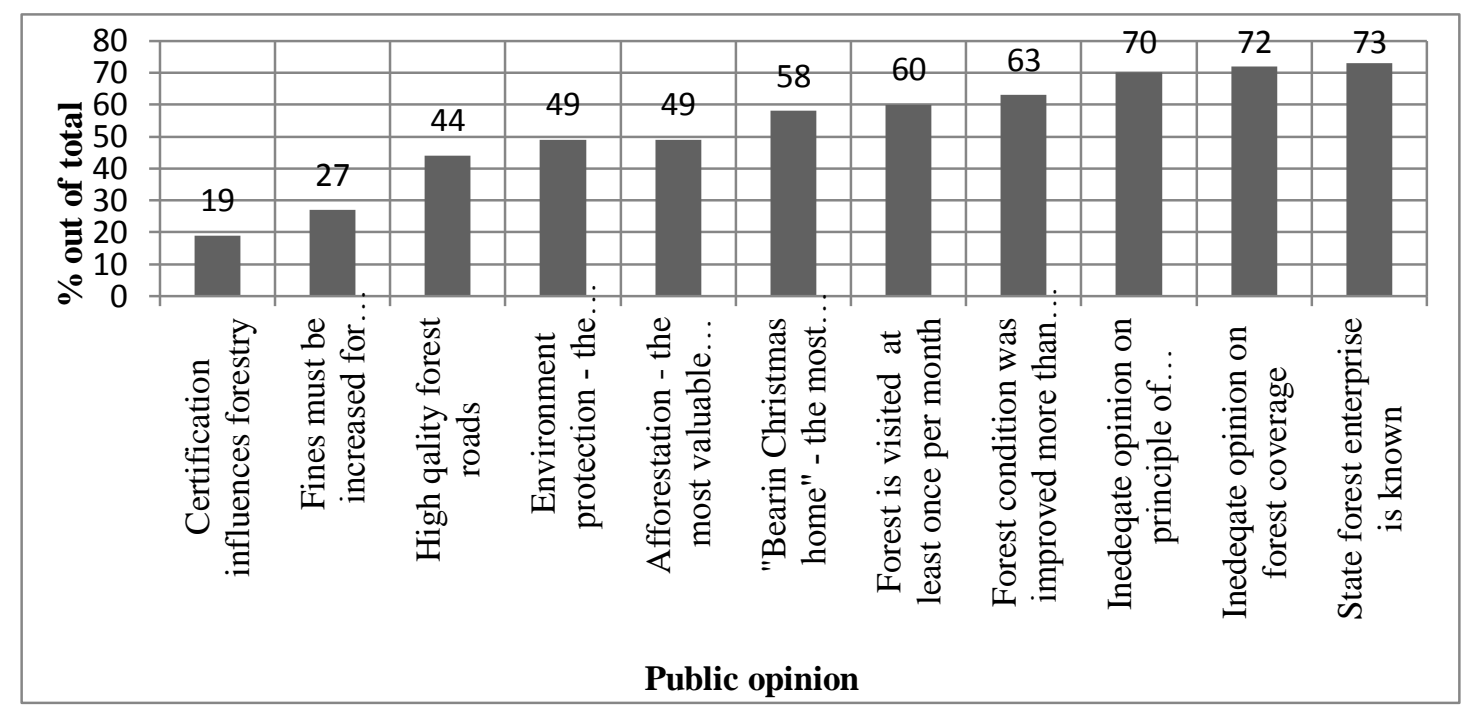

Figure 3. Some attitudes on forestry and social and nature protection activity performed by Kaišiadoriai state forest enterprise

\section{CONCLUSIONS AND DISCUSSION}

Survey results revealed positive respondents' opinion on forest reforestation and protection activities performed by Kaišiadoriai SFE. Also, the high rates were assigned to the activities involving public (e.g. collaboration with children and locals, event on Christmas time called "Bearing Christmas home", placing nesting-box). It was determined that most of public was interested in environment protection, building recreational infrastructure and hunting activities performed by Kaišiadoriai SFE. Respondents were willing to develop recreational and environmental infrastructure as well as to increase its quality. The involvement of the public in forestry activities was the reason that had effect in forming positive attitudes.

Despite the prevailing interviewers' attitude, that Kaišiadoriai SFE successfully managed state forests, survey data revealed mismatching public opinion with official forestry data provided in statistics. These contrasts were very clear when discussing issues like forest coverage (was increasing, in fact), cutting intensity (accumulated standing stock was increasing, in fact) and environmental protection (requirements and areas were increasing, in fact). The incorrect opinion was formed because the problems in dissemination of information in state forestry sector. As a fact, the main respondents' information was gained during direct forest visits or directly from friends. Yet, these information sources are biased.

The comparison between surveys conducted in 2007 and 2014 highlighted the problem on increasing amount of young generation which was indifferent to forestry. Due to lack of contemporary information dissemination strategy (e.g. social networks, apps for mobile phones) that would meet informational needs of young generation, the problem was deepening.

According to authors' opinion one of the possibilities to raise public's awareness in the forestry issues would be the development of participatory based processes, with assignment of decision rights. Also, to deal with problems addressed by generations, social status and etc. The long-term strategy concerning with information dissemination has to be adopted and integrated to forest development strategy.

\section{REFERENCES}

1. Bliss, J. C., Martin, A. J. 1989. Identifying NIPF Management Motivations with Qualitative Methods. Forest Science, Vol. 35, No. 2, pp. 601-622.

2. Braziulis, R. 2015. Why Forest Management Plan Is Important for the Public. Published 14/09/2015. Available at: http://mobile.kasdien.lt/Pradzia/Patarimai/Gamta/Kodel-visuomenei-svarbus-miskotvarkos-projektas. (accessed on 01/10/2015) (In Lithuanian)

3. Brukas, V., Kuliešis,A., Sallnäs, O., Linkevičius, E. 2011. Resource availability, planning rigidity and Realpolitik in Lithuanian forest utilization. Natural Resources Forum, Vol. 35, Iss. 1, pp. 77-88. http://dx.doi.org/10.1111/j.1477-8947.2011.01380.x 
4. Buchowska, G. 2005. Analysis of Relations Between State Forest Enterprises and Public / master theses. Superviser: Algirdas Rutkauskas Lithuanian University of Agruculture, Academy, pp 69. (In Lithuanian)

5. Čekanavičius, V., Murauskas, G. 2006. Statistics and its Applications, Vilnius: TEV, pp. 239. (In Lithuanian)

6. Directorate General of State Forests. 2009. Lets Develop Forets Future Together. Published on 13/03/2009. Available at http://www.gmu.lt/ziniasklaida/pid=\%7Bsubmenu.id\%7D;p.20;n.40;nid.1078;/. (accessed on 01/10/2015) (In Lithuanian)

7. Directorate General of State Forests. 2011. Regarding Confirmation of the Order Concerning Inventory of List of Economical, Ecological and Social Outputs. Order of the Director of Directorate General of State Forests No. 1B-408 published on 05/10/2011. Vilnius. (In Lithuanian)

8. Forest Act. 2001. Adopded by Seimas of the Rebublic of Lithuania, came into force 20010101 . Last amendment 20150514. Available at www.lrs.lt (accessed on 11/02/2015). (In Lithuanian)

9. Forestry Commision. 2011. Results from the UK Survey of Public Opinion of Forestry. Economics \& Statistics, Edinburgh, pp. 37.

10. Hokajärvi, R., Hujala, T., Leskinen, L. A., Tikkanen, J. 2009. Effectiveness of Sermon Policy Instruments: Forest Management Planning Practices Applying the Activity Theory Approach. Silva Fennica, Vol. 43, No. 5, pp. 889-905. http://dx.doi.org/10.14214/sf.178

11. Hugosson, M., Ingemarson, F. 2004. Objectives and Motivations of Small-scale Forest Owners: Theoretical Modelling and Qualitative Assessment. Silva Fennica, Vol. 38, No. 2, pp. 217-231. http://dx.doi.org/10.14214/sf.430

12. Kairiūkštis, L. 2003. Forestry yearbook: XX century. Kaunas, "Naujas lankas”. pp. 19-29. [in Lithuanian]

13. Karazija, S., Ozolinčius, R. 2011. Forests and Forestry: Myths and Reality. Science and Life, No. 8-9, pp 21-23. [in Lithuanian]

14. Kardelis, K. 2007. Methodhology of Scientific Research and Methods: Manual, Šiauliai: Lucilijus, pp. 400. [in Lithuanian]

15. Lönnstedt, L. 1997. Non-industrial private forest owners' decision process: a qualitative study about goals, time perspective, opportunities and alternatives. Scandinavian Journal of Forest Research, Vol. 12, pp. 302-310. http://dx.doi.org/10.1080/02827589709355414

16. Lithuanian Department of the Statistics. 2014. Statistical Yearbook of Lithuania, Vilnius, Lithuanian Department of the Statistics, pp. 686.

17. Ministry of Environment and State Forest Service. 2009. Lithuanian Statistical Yearbook of Forestry,Kaunas: Lutute, pp. 152.

18. Ministry of Environment and State Forest Service. 2014. Lithuanian Statistical Yearbook of Forestry, Kaunas: Lutute, pp. 184.

19. Ministry of Environment. 2006. The analysis of public opinion on the main forestry issues in Lithuania. Research report. Lithuanian Institute of Forestry, pp. 251. (In Lithuanian)

20. Minkevičiené, A. 2015. Benjaminas Sakalauskas: "The War Is Not on the End”. Published on 23/05/2015. Available at http://www.grokiskis.lt/temos/aktualijos/2015/05/23/benjaminas-sakalauskaskaras--nesibaigia. (accessed on 02/10/2015) (In Lithuanian)

21. Mizaraite, D. 2001. Objectives, Problems and Needs of the Private Forest Owners as well as Dependence on Various Factors. Miškininkystè, No. 1, pp. 33-46. (In Lithuanian)

22. Mizaraite, D., Mizaras, S. 2005A. The Formation of Small-scale Forestry in Countries with Economies in Transition: Observations from Lithuania. Small-scale Forest Economics, Management and Policy, Vol. 4, Iss. 4, pp. 437-450.

23. Mizaraite, D., Mizaras, S. 2005B. Empirically Based Grouping in Private Forest Owners in Lithuania. Baltic Forestry, Vol. 11, No. 1, pp. 80-87.

24. Pivoriūnas, A., Lazdinis, M. 2004. Needs of Private Forest Owners in the Context of Changing Political Systems: Lithuania as a Case Study. Small-scale Forest Economics Management and Policy, Vol. 3, Iss. 2, pp. 191-202.

25. Rudzkienè V. 2005. Social Statistics. Manual. Vilnius: MRU, pp. 260. (In Lithuanian)

26. Stanislovaitis, A., Brukas, V., Kavaliauskas, M., Mozgeris, G. 2015. Forest Owner is More than Her Goal: a Qualitative Typology of Lithuanian Owners. Scandinavian Journal of Forest Research, Vol. 30, Iss. 5, pp. $478-491$. http://dx.doi.org/10.1080/02827581.2014.998706

27. Tidikis, R. 2003. Methodology in Social Sciences. Manual. Vilnius: LTU, pp. 626. (In Lithuanian)

28. Vingrienè, V. 2013. Only Profit in Private Forest Owner Heads. Published on 23/09/2013. Available at http://zali.lt/miskai/apiemus-raso-privaciu-misku-savininku-galvose-tik-pelnas/. (accessed on 12/04/2015) (In Lithuanian) 